\title{
EFFECT OF THE CULTIVATION MEDIA TREATED WITH DIFFERENT IRRIGATION WATER QUALITIES AND COMPOST LEVELS ON THE PRODUCTIVITY OF TOMATO PLANTS IN NORTH DELTA OF EGYPT. \\ Hassanein, A.H.A; M. A. Aiad; A.M.M Abdel-Fattah and A, Kh. Amer Soils, Water and Environment Res. Institute, Agric. Res. Centre, Giza, Egypt
}

\begin{abstract}
A field experiment was carried out in plastic greenhouses at Sakha Agricultural Research Station to study the effect of different cultivation media, irrigation water sources and compost levels on fresh yield of tomato and NPK contents of leaves and $\mathrm{C} / \mathrm{N}$ ratio of rice straw bales. Split plot design with four replicates was used. The obtained results could be summarized as follows:

1) Fresh yield of tomato grown on clay soil was higher than that grown on rice straw bales.

2) Fresh yield of tomato was decreased significantly with irrigation by well water or blended fresh with well water compared to fresh water.

3) Addition of 20 ton of compost/fed. gave the highest fresh yield of tomato, while zero level leads to achieve the lowest yield.

4) $\mathrm{N}$ and $\mathrm{P}$ contents in tomato leaves were higher under cultivation on clay soil than rice straw bales, while $\mathrm{K}$ took the opposite trend. Concerning the irrigation water sources, the contents of these elements were higher with fresh water than blended and well water, as well as, addition of 20 ton compost /fed. achieve the highest values of NPK content compared with other levels.

5) The $\mathrm{C} / \mathrm{N}$ ratio of rice straw bales is decreased after tomato harvesting comparing to that before the experiment. Using fresh water or blended water gave the lowest value of $\mathrm{C} / \mathrm{N}$ ratio with tomato plants. Whereas, well water tend to decrease the rate of decomposition. The increase of compost application level up to 20 ton/fed. leads to consequently increase the decomposition of rice straw and clearly decrease $\mathrm{C} / \mathrm{N}$ ratio.

Generally, it could be concluded that compost application at the rate of 20 ton/fed. to rice straw bales as a growing media was the recommended treatment which produced the highest total tomato yield and quality fruits under greenhouse in Egypt. Thus, these treatments can replace completely or partially instead of mineral fertilizers, which protect the environment chemical pollution and its harmful effect on human and animal health besides reducing the production costs.

Keywords:Tomato plants, compost levels, irrigation water, yield and North Delta of Egypt.
\end{abstract}

\section{INTRODUCTION}

The agricultural wastes cause real problems to the farmer to get rid of them instead of their nutritional and organic valuables for semi-arid and arid lands in Egypt. Small-scale farmers are facing increasingly more difficult task of producing sufficient food for own consumption, while generating cash income for other needs. 
Many researchers showed the low organic matter content of the soils (0.5$2 \%)$. It is well known that organic matter particularly in clay soil improves the soil structure, increases the water and fertilizer retention capacity in the root zone and increases the microbial activity of the soil, in addition, useful plant nutrients are lost when about 5 million ton of rice straw are disposed annually by burning. Salem (1988) reported that adding organic manure as fertilizer led to decreasing soil $\mathrm{pH}$ which results in increasing nutrients solubility and availability to the plant. Abo El-Defan (1990) found that addition of chicken manure increased fresh and dry yields of tomato shoots, fruits and the concentration of $\mathrm{N}, \mathrm{P}$ and $\mathrm{K}$ in both shoots and fruits.

To reuse of the agriculture wastes for keeping the soil fertility should be the first composting to modify the $\mathrm{C} / \mathrm{N}$ ratio to be required and avoided weeds seeds, pests, diseases and etc., Manishi et al (1996) found that applying organic manure of compost led to an increase in concentration and uptake of N, P and K in different tomato plant organs. Cheuke et al (2003) illustrated that up to $10 \%$ increase in yield of tomato and peppers have been reported with response to compost application. Keener et al (2000) found that increase of compost addition improved soil fertility in terms of organic $\mathrm{C}$ and $\mathrm{N}$ content, permeability, plant available water capacity and air filled porosity.

Anand and Yadudvanshi (2000) reported that the soil organic carbon, available $\mathrm{Zn}$ and $\mathrm{Mn}$ were significantly decreased in treatments receiving inorganic fertilizers compared to the treatments involving organics fertilizersEl-Aidy (1986) used rice straw as cultivation media for tomato and summarized that the best results were obtained from straw bales half buried in the soil during winter cultivation from buried bales during spring cultivation. The increase of the total yield for the best treatment and control were 0.7 and $0.33 \mathrm{~kg} / \mathrm{plant}$ in winter and spring cultivation, respectively. Janet et al. (2004) concluded that early yield, total yield and nutrient uptake in tomato leaves slightly differed when plants grown on rice straw in two successive seasons. Concerning plant growth and nutrients uptake in vegetative parts, no significant differences were obtained. All the cultivation media substrates (Rice straw bales and nutrients) under investigation led to an increment in organic matter content at the end of the growing seasons comparing with clay or sand only. Rice straw covered with sandy soil gave the highest fruit yield, fresh and dry weight and total $\mathrm{N}, \mathrm{P}, \mathrm{K}$ accumulation in vegetative parts and fruits. Total dry matter content and total N, P, K accumulation in vegetative parts were increased with progress of plant age till 120 days from planting and then declined.

Abd Alla (1995) found that the growing of tomato on half buried straw bales led to significant increases in number of leaves and plant fresh and dry weights at most stages in two successive years. She also, concluded that early yield was significantly increased by using straw bales half buried in the soil, where fruits number was increased by $255 \%$ and fruits weight by $282 \%$ compared to the soil media (control).

Because of water scarcity problems in arid regions, it has become of primary importance to search for alternative sources of water for agriculture irrigation. Brackish water can be used for irrigation of various crops. In spite of the fact that saline water used for agriculture is associated with some 
reduction in yield, it can successfully be applied to irrigation, coupled with improved irrigation technology such as subsurface drip irrigation. When brackish water is skillfully used for irrigation, it can contribute to the successful production of crops (Mizrahi and pasternake, 1985).

Abo-soliman et al.(2002) concluded that the irrigation with fresh water achieve the highest fruit yield of tomato, yield per plant, juice percentage and vitamin c. while the yield of tomato is decreased by 11.48 and $25.71 \%$ when irrigation by alternative well water with fresh and well water, respectively.

The aim of this work is studied the effect of different cultivation media, irrigation water sources and compost levels on fresh yield of tomato and NPK contents of leaves and $\mathrm{C} / \mathrm{N}$ ratio of rice straw bales.

\section{MATERIALS AND METHODS}

A field experiment was carried out during season of 2013 on a clay soil inside plastic greenhouse located at Sakha Agricultural Research Station, Kafr El-Sheikh Governorate, North Delta Region, Egypt, to study the effect of different cultivations media, irrigation water sources and compost levels on fresh yield of tomato and NPK contents of leaves and $\mathrm{C} / \mathrm{N}$ ratio of rice bales. The experiment was carried out in greenhouses with dimension $6 \mathrm{~m}$ width and $24 \mathrm{~m}$ length for each treatment. The initial physical and chemical characteristics of studied soil were determined according to klute (1986) and Page et al. (1982) as shown in Table (1a). Also Table (1b) presents the chemical analysis of different irrigation water sources.

Table (1a): Some physical and chemical properties of the experimental soil.

\begin{tabular}{|c|c|c|c|}
\hline Property & Value & Property & Value \\
\hline \multirow[t]{2}{*}{ pH (1:2.50) susp. } & 8.10 & O.M. \% & 0.78 \\
\hline & & $\mathrm{C} / \mathrm{N}$ ratio & 9.64 \\
\hline \multirow[t]{2}{*}{$E C\left(d_{S m^{-1}}\right)$} & 2.99 & & \\
\hline & & Available (N) mg/kg soil & 89.18 \\
\hline Soluble anions meq/L:- & & Available $(P) \mathrm{mg} / \mathrm{kg}$ soil & 24.33 \\
\hline $\mathrm{CO}_{3}^{2-}$ & NIL & Available (K) mg/kg soil & 825.00 \\
\hline $\mathrm{HCO}_{3}^{-}$ & 5.01 & Particle size distribution:- & \\
\hline $\mathrm{Cl}^{-}$ & 14.00 & Clay $\%$ & 50.41 \\
\hline $\mathrm{SO}_{4}{ }^{2-}$ & 12.84 & Silt \% & 27.92 \\
\hline Soluble cations meq/L:- & & F.sand \% & 15.70 \\
\hline $\mathrm{Ca}^{2+}$ & 4.84 & C.sand \% & 4.06 \\
\hline $\mathrm{Mg}^{2+}$ & 6.55 & Textural class & clayey \\
\hline $\mathrm{Na}^{+}$ & 19.96 & $\mathrm{CaCO3} \%$ & 4.11 \\
\hline \multirow[t]{2}{*}{$\mathrm{K}^{+}$} & 0.50 & Bulk density $\left(\mathrm{gcm}^{-3}\right)$ & 1.22 \\
\hline & & W.P $(\%)$ & 22.88 \\
\hline CEC meq $/ 100 \mathrm{~g} \mathrm{~s}$ & 17.40 & FC \% & 40.94 \\
\hline
\end{tabular}


Table (1b): Chemical analysis of different irrigation water.

\begin{tabular}{|c|c|c|c|c|c|c|c|c|c|c|}
\hline \multirow[b]{2}{*}{$\begin{array}{l}\text { Water } \\
\text { sources }\end{array}$} & \multirow{2}{*}{$\begin{array}{c}\mathrm{EC} \\
\mathrm{dS} / \mathrm{m}\end{array}$} & \multicolumn{4}{|c|}{ Anions meq/L } & \multicolumn{4}{|c|}{ Cations meq/L } & \multirow[b]{2}{*}{ SAR } \\
\hline & & $\mathrm{CO}_{3}{ }^{2-}$ & $\mathrm{HCO}_{3}^{-}$ & $C r$ & $\mathrm{SO}_{4}{ }^{2-}$ & $\mathrm{Ca}^{2+}$ & $M g^{2+}$ & $\mathrm{Na}^{+}$ & $K^{+}$ & \\
\hline Fresh (F) & 0.50 & --- & 1.20 & 1.80 & 2.20 & 1.70 & 1.00 & 2.00 & 0.50 & 1.72 \\
\hline Well (W) & 3.10 & --- & 5.60 & 15.78 & 10.70 & 6.60 & 5.58 & 18.60 & 1.30 & 7.53 \\
\hline Blended $(F, W)$ & 2.00 & --- & 4.30 & 10.67 & 6.93 & 4.85 & 3.41 & 12.66 & 0.98 & 6.23 \\
\hline
\end{tabular}

On the other hand, samples were taken from rice straw bales to determine N, P, K and organic carbon contents as shown in Table (2).

Preliminary preparations inside greenhouses were implemented before transplanting of tomato as follow:

The soil of the greenhouse was divided into four wide furrows, each one meter width. Rice straw bales were arranged in four rows $(75 \mathrm{~cm})$ width for each greenhouse. Each furrow had two trickle irrigation lateral lines, with $4 \mathrm{~L} / \mathrm{hr}$ discharge and $50 \mathrm{~cm}$ spacing of each emitter.

Table (2): Chemical analysis of Farm Compost and Rice Straw bales.

\begin{tabular}{|l|c|c|c|c|c|c|}
\hline Elements & Rate (ton/fed.) & \multicolumn{4}{|c|}{$\%$} & $\mathbf{C} / \mathbf{N}$ \\
\hline & & $\mathbf{N}$ & $\mathbf{P}$ & $\mathbf{K}$ & $\mathbf{C}$ & ratio \\
\hline & 5 & 1.39 & 1.38 & 1.29 & 27.60 & 19.86 \\
\hline Farm Compost & 10 & 1.45 & 1.41 & 1.34 & 30.25 & 20.86 \\
\hline & 15 & 1.76 & 1.48 & 1.39 & 37.18 & 21.13 \\
\hline Rice straw bales & 20 & 1.98 & 1.67 & 1.45 & 48.60 & 24.55 \\
\hline & & 0.38 & 1.25 & 0.85 & 25.30 & 66.58 \\
\hline
\end{tabular}

All the other agronomic practices including pest control and applied the recommended doses from the mineral fertilizers in the form of ammonium nitrate, superphosphate and potassium sulphate carried out according to the MALR recommendations.

Tomato cultivar (Lycopersion esculentum,L) variety flora was transplanted on Jan. $1^{\text {th }}, 2013$ and harvested on $23^{\text {rd }}$ of June,2013.

Farm compost which decomposed from previous rice bales was added to the new rice bales. The rice straw bales were moisten by irrigation water via drip irrigation system for 7 days (3-4 hours a day) to remove soil particles that contaminated rice straw bales.

A split plot design with four replicates was used for the experiment. The applied treatments were described as follows:-

1)Cultivation media:

a- Rice straw bales.

b- Ordinary clay soil.

2)Water sources i.e. fresh water $(F)$, well water $(W)$ from local well and blended well water with fresh $(\mathrm{W}, \mathrm{F})$ at ratio of $1: 1(2.00 \mathrm{dS} / \mathrm{m})$.

3) Application of compost levels:

Zero level (control), 5 ton/fed., 10 ton/fed., 15 ton/fed. and 20 ton/fed.

The tomato crop was picked once a week from each greenhouse to measure the total yield $(\mathrm{kg})$ and weight of fruits per plant were calculated from the whole yield. Juice of the representative samples (20 fruits) was 
taken for measuring fruit quality. It was extracted, estimated and used for determination of ascorbic acid, total soluble solids (\%) and total acidity according to A.O.A.C. (1990). The plant samples were analyzed for nitrogen according to Cottenie et al. (1982), phosphorus according to Olsen et al. (1965) and potassium according to Page et al. (1982). Obtained data were statistically analyzed (Gomez and Gomez, 1984).

\section{RESULTS AND DISCUSSION}

Effect of different treatments on NPK contents in tomato leaves:

Results presented in Table (3) indicate that the nitrogen, phosphorus and potassium percentage in leaves of tomato are affected by cultivation media. The nitrogen and phosphorus are highly significant increase in leaves of tomato cultivated in the clay soil compared with those grown on rice straw bales. This may be due to the immobilization of nitrogen in straw bales during the decomposition whereas, the $\mathrm{N}$ and $\mathrm{P}$ contents in the clay soil are $4.20 \%$ and $1.54 \%$, while the content of these elements in rice straw pales are $3.35 \%$ and $1.40 \%$ respectively.

Table (3): $N, P$ and $K \%$ in tomato leaves as affected by different treatments under protected greenhouse during winter season 2013.

\begin{tabular}{|c|c|c|c|c|}
\hline Parameters & Treatments & $\mathbf{N} \%$ & $\mathbf{P} \%$ & K \% \\
\hline \multirow{6}{*}{ 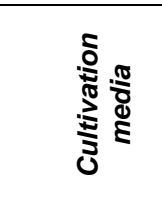 } & Rice straw bales & 3.35 & 1.40 & 4.17 \\
\hline & Clay soil & 4.20 & 1.54 & 3.70 \\
\hline & Average & 4.29 & 1.47 & 3.94 \\
\hline & F test & $\star *$ & $\star \star$ & $\star *$ \\
\hline & LSD at 0.05 level & 0.019 & 0.077 & 0.066 \\
\hline & LSD at 0.01 level & 0.035 & 0.142 & 0.12 \\
\hline \multirow{7}{*}{$\begin{array}{l}y \\
d \\
\vdots \\
0 \\
0 \\
\vdots \\
\frac{1}{\pi}\end{array}$} & Fresh & 4.29 & 1.67 & 4.61 \\
\hline & Well & 4.04 & 1.10 & 3.60 \\
\hline & Blended & 4.55 & 1.55 & 3.60 \\
\hline & Average & 4.29 & 1.47 & 3.94 \\
\hline & $\mathrm{F}$ test & $\star *$ & $\star \star$ & ** \\
\hline & LSD at 0.05 level & 0.05 & 0.148 & 0.216 \\
\hline & LSD at 0.01 level & 0.066 & 0.20 & 0.293 \\
\hline \multirow{9}{*}{ 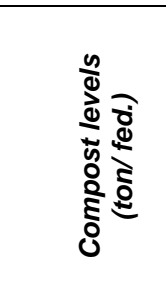 } & 0 & 2.68 & 0.84 & 2.75 \\
\hline & 5 & 3.79 & 1.33 & 3.53 \\
\hline & 10 & 4.50 & 1.51 & 4.12 \\
\hline & 15 & 4.90 & 1.72 & 4.48 \\
\hline & 20 & 5.42 & 1.94 & 4.85 \\
\hline & Average & 4.29 & 1.47 & 3.94 \\
\hline & F test & $\star \star$ & $\star *$ & $\star \star$ \\
\hline & LSD at 0.05 level & 0.049 & 0.142 & 0.21 \\
\hline & LSD at 0.01 level & 0.065 & 0.188 & 0.28 \\
\hline \multirow{4}{*}{ 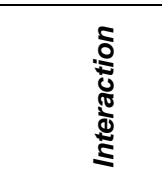 } & Cultivation $\mathrm{x}$ Water & ** & n.s & ** \\
\hline & Cultivation $\times$ Compost & ** & ** & ** \\
\hline & Water x Compost & ** & ** & ** \\
\hline & Cultivation $\mathrm{x}$ Water $\times$ Compost & ** & ** & ** \\
\hline
\end{tabular}


On the other hand, the potassium percentage is lower in clay soil than rice straw bales. The $\mathrm{K} \%$ was $3.70 \%$ in clay soil while in rice bales was $4.17 \%$.

Data also revealed that the irrigation by different water sources had a highly significant effect on NPK contents in tomato leaves, whereas these elements are clearly increased when fresh water used in irrigation compared to well and blended water. These results may be attributed to the irrigation by saline water, and consequently decreased NPK concentration in leaves of tomato, my by inhibit water and nutrient uptake by plant.

On the other hand data indicate that, the compost levels strongly affect NPK content of leaves of tomato. Increasing compost levels up to 20 ton/fed increase NPK content, from 2.68, 0.84 and 2.75 to $4.29,1.47$ and 3.94, respectively. This result is in agreement with Abu El Defan (1990), Salem (1988) and Selim et al. (2007).

The combination between either cultivation media and water sources or cultivation media and compost levels had highly significant effect on $\mathrm{N}$ and $\mathrm{P}$ but not significant with $\mathrm{K}$. While the interaction between water sources, compost and cultivation, had highly significantly affected on NPK content in leaves.

\section{Effect of interaction between different treatments on nutrients content} of tomato leaves:

Tables $(4,5$ and 6$)$ showed nutrients content in tomato leaves as influenced by cultivation media, water sources and compost. Cultivation of tomato in rice straw bales significantly resulted in increasing nitrogen and potassium percentage compared to clay soil. On the other hand phosphour percentage was increased by $9.1 \%$ as a result to cultivation in clay soil compared to cultivation on rice straw bales.

Table (4): Effect of interaction between cultivation media, water sources and compost levels on nitrogen percentage in tomato leaves.

\begin{tabular}{|l|c|c|c|c|c|c|}
\hline Cultivation & Water & \multicolumn{5}{|c|}{ Compost levels (ton/fed.) } \\
\hline media & sources & 0 & 5 & 10 & 15 & 20 \\
\hline & Fresh & 2.49 & 4.28 & 4.62 & 5.13 & 5.41 \\
\hline Rice straw & Well & 2.74 & 4.09 & 4.22 & 4.79 & 5.29 \\
\hline bales & blended & 2.81 & 4.42 & 4.90 & 5.14 & 5.44 \\
\hline & & & & & & \\
\hline & Fresh & 2.69 & 3.73 & 4.36 & 4.68 & 5.53 \\
\hline Clay soil & Well & 2.35 & 3.49 & 4.00 & 4.39 & 5.11 \\
\hline & blended & 2.98 & 3.80 & 4.91 & 5.28 & 5.78 \\
\hline
\end{tabular}


Table (5): Effect of interaction between cultivation media, water sources and compost levels on phosphour percentage in tomato leaves.

\begin{tabular}{|l|c|c|c|c|c|c|}
\hline Cultivation & Water & \multicolumn{6}{|c|}{ Compost levels } \\
\hline media & sources & 0 & 5 & 10 & 15 & 20 \\
\hline & Fresh & 0.71 & 1.42 & 1.66 & 2.31 & 2.51 \\
\hline Rice straw & Well & 0.72 & 0.83 & 1.00 & 1.21 & 1.50 \\
\hline bales & blended & 0.70 & 1.50 & 1.61 & 1.63 & 1.75 \\
\hline & & & & & & \\
\hline & Fresh & 0.81 & 1.75 & 1.89 & 2.11 & 2.45 \\
\hline Clay soil & Well & 0.83 & 0.96 & 1.23 & 1.30 & 1.42 \\
\hline & blended & 1.30 & 1.52 & 1.70 & 1.79 & 1.99 \\
\hline & & & & & & \\
\hline
\end{tabular}

Table (6): Effect of interaction between cultivation media, water sources and compost levels on potassium percentage in tomato leaves.

\begin{tabular}{|l|c|c|c|c|c|c|}
\hline Cultivation & Water & \multicolumn{5}{|c|}{ Compost levels (ton/fed.) } \\
\hline media & sources & 0 & 5 & 10 & 15 & 20 \\
\hline & Fresh & 3.20 & 4.45 & 5.20 & 5.55 & 6.17 \\
\hline Rice straw & Well & 2.88 & 3.34 & 4.12 & 4.29 & 5.05 \\
\hline bales & blended & 1.99 & 3.77 & 4.08 & 4.12 & 4.37 \\
\hline & & & & & & \\
\hline & Fresh & 2.85 & 3.47 & 4.65 & 5.30 & 5.30 \\
\hline Clay soil & Well & 2.67 & 3.00 & 3.27 & 3.47 & 3.88 \\
\hline & blended & 2.72 & 3.14 & 3.40 & 4.12 & 4.32 \\
\hline
\end{tabular}

This increase may be due to increasing the available $P$ in soil which facilitates $P$ uptake due to irrigation by blended and fresh water which increased the concentration of potassium and phosphour in tomato leaves followed by blended fresh water with well water. While the concentration of nitrogen in tomato leaves was decreased with irrigation by fresh water. The highest value of nitrogen percentage was obtained with irrigation by blended fresh water with well water. The decrease in potassium and phosphour in tomato leaves may be due to that the increasing the salinity in irrigation water decreased the potassium content in plants. The increasing levels of compost from zero to 20 ton/fed. increased the nutrients content of tomato leaves. This may be due to the decomposition of compost which supplied more available nutrient elements and release of organic and inorganic acids during decomposition which slightly reduce the soil $\mathrm{PH}$ which affected the solubility and availability of $\mathrm{N}, \mathrm{P}$ and $\mathrm{K}$.

The interaction effect on nitrogen percentage was obtained from cultivation in clay soil; irrigation by blended of fresh water with well water and application of $20 \mathrm{ton} / \mathrm{fed}$. while the highest values of potassium and phosphour were achieved from combination between cultivation on rice straw bales, irrigation by fresh water and application of 20 ton compost / fed. 


\section{Effect of different treatments on fresh yield:}

Data in Table (7) reveal that, there is a highly significant effect on fresh yield of tomato. The cultivation on ordinary clay soil leads to increase the fresh yield of tomato by $4.6 \%$ over cultivation on rice straw bale. The decrease in yield of tomato which be grown in rice straw bale may be due to the deepest roots of tomato in clay soil than of in straw bales which increase nutrients uptake, from the soil media.

Table (7): Early, mid-season, late season and total fresh yield $\left(\mathrm{kg} / \mathrm{m}^{2}\right)$ of tomato plants as affected by different treatments during growing season.

\begin{tabular}{|c|c|c|c|c|c|}
\hline \multirow[b]{2}{*}{ Parameters } & \multirow[b]{2}{*}{ Treatments } & \multicolumn{3}{|c|}{ Harvesting stages } & \multirow{2}{*}{$\begin{array}{c}\text { Total } \\
\text { Yield } \\
\left(\mathrm{kg} / \mathrm{m}^{2}\right)\end{array}$} \\
\hline & & Early & $\begin{array}{l}\text { Mid } \\
\text { season }\end{array}$ & Late & \\
\hline \multirow{6}{*}{ 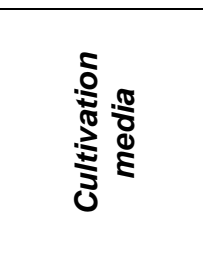 } & Rice straw bales & 1.75 & 5.41 & 2.25 & 9.41 \\
\hline & Clay soil & 1.47 & 5.49 & 2.90 & 9.86 \\
\hline & Average & 1.61 & 5.45 & 2.58 & 9.64 \\
\hline & F test & ---- & $-\cdots--$ & ---- & * \\
\hline & LSD at 0.05 level & $-\overline{---}$ & $-\overline{---}$ & ---- & 0.398 \\
\hline & LSD at 0.01 level & ---- & ---- & ---- & ---- \\
\hline \multirow{7}{*}{ 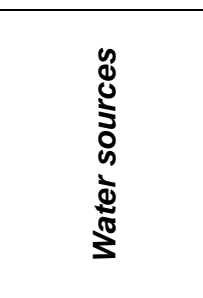 } & Fresh & 1.75 & 5.90 & 3.23 & 10.88 \\
\hline & Well & 1.10 & 4.76 & 2.92 & 8.78 \\
\hline & Blended & 1.55 & 5.25 & 2.46 & 9.26 \\
\hline & Average & 1.47 & 5.30 & 2.87 & 9.64 \\
\hline & F test & +--- & ---- & ---- & ** \\
\hline & LSD at 0.05 level & ---- & ---- & ---- & 1.13 \\
\hline & LSD at 0.01 level & ---- & ---- & ---- & 1.57 \\
\hline \multirow{9}{*}{ 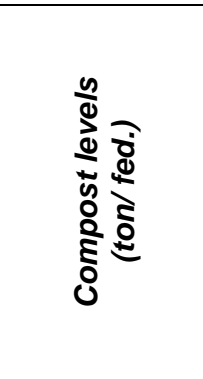 } & 0 & 0.75 & 4.45 & 2.28 & 7.48 \\
\hline & 5 & 1.25 & 4.85 & 2.25 & 8.35 \\
\hline & 10 & 1.45 & 5.00 & 2.99 & 9.44 \\
\hline & 15 & 1.75 & 5.41 & 3.10 & 10.26 \\
\hline & 20 & 1.95 & 7.48 & 3.23 & 12.66 \\
\hline & Average & 1.43 & 5.44 & 2.77 & 9.64 \\
\hline & F test & ---- & ---- & ---- & ** \\
\hline & LSD at 0.05 level & ---- & ---- & ---- & 0.81 \\
\hline & LSD at 0.01 level & ---- & ---- & ---- & 1.06 \\
\hline \multirow{3}{*}{ 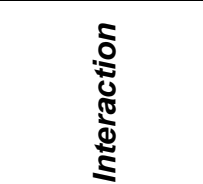 } & Cultivation $\times$ Compost & ---- & ---- & ---- & ** \\
\hline & Water x Compost & ---- & ---- & ---- & * \\
\hline & Cultivation $\mathrm{x}$ Water $\mathrm{x}$ Compost & --- & --- & --- & ** \\
\hline
\end{tabular}

Concerning the effect of irrigation water sources, data in Table (7) show that the yield of tomato is reduced significantly by $19.30 \%$ and $14.89 \%$ due to irrigation with well and blended water; respectively as compared to fresh water. This result is agreement with Mass (1984) according to this 
trend, tomato yield reduced by about $75 \%$ when irrigated by water with $\mathrm{EC}_{\mathrm{w}}$ equals $2.00 \mathrm{dS} / \mathrm{m}$.

Concerning the compost levels, data show that there is a highly significant effect on tomato fresh yield due to compost application levels up to $20 \mathrm{ton} / \mathrm{fed}$. This increase in tomato fresh yield is $11.48 \% 26.03 \%, 36.98 \%$ and $69.16 \%$ with $5,10,15$ and 20 ton/fed compost over the control, respectively. It was observed from data in Table (7) that the interaction cultivation on between all treatments under study was high significant

\section{Effect of interaction between different treatments on Fresh yield of tomato:}

Data in Table (8) showed that the fresh yield of tomato increased by $4.66 \%$ due to cultivation in clay soil compared to cultivation in rice straw bales.

Table (8): Effect of interaction between cultivation media, water sources and compost levels on fresh yield of tomato $\left(\mathrm{kg} / \mathrm{m}^{2}\right)$.

\begin{tabular}{|l|c|c|c|c|c|c|}
\hline Cultivation & Water & \multicolumn{5}{|c|}{ Compost levels } \\
\hline media & sources & 0 & 5 & 10 & 15 & 20 \\
\hline & Fresh & 7.21 & 8.89 & 10.13 & 11.37 & 14.32 \\
\hline Rice straw & Well & 7.20 & 7.40 & 7.98 & 9.66 & 12.46 \\
\hline bales & blended & 7.13 & 7.54 & 8.96 & 8.97 & 11.96 \\
\hline & & & & & & \\
\hline & Fresh & 9.81 & 10.60 & 10.95 & 11.59 & 13.91 \\
\hline Clay soil & Well & 5.74 & 6.96 & 9.31 & 10.05 & 11.06 \\
\hline & blended & 7.83 & 8.68 & 9.30 & 9.93 & 12.29 \\
\hline
\end{tabular}

It was also clear that the fresh yield of tomato markedly increased by 19.3 and $14.89 \%$ with irrigation by fresh water compared to irrigation by well water and blended of fresh water with well water. The decrease in fresh yield of tomato under irrigation by well water may be due to the accumulation of salts in the rote zone.

Also, data indicated that the fresh yield of tomato were increased by 11.48 , $26.03,36.98$ and $69.16 \%$ due to applying compost of rice straw compared to check treatment. The increase in fresh yield of tomato according to applying compost is may be due to their beneficial effects on the physio-chemical and biological characteristics of soil which in turn influence the growth and increase plants production. In other words, compost applications improves moisture retention in the soil and are a good source of essential nutrients as well they beneficially affect micro flora activities, improve soil structure and decrease soil $\mathrm{pH}$ after cultivation. It is worthy to mention that the highest fresh yield of tomato was achieved from interaction between cultivation of tomato in rice straw bales, irrigation by fresh water and application of compost at rate of 15 ton / fed.

While the lowest value of fresh yield of tomato was obtained from combination between cultivation in clay soil, irrigation by well water and without compost application. 


\section{Fruit quality}

Values of vitamin $\mathrm{C}$, total soluble solids and total acidity as affected by different treatments are presented in Table (9), the results show that the vitamin $\mathrm{C}$ in tomato juice is highly significantly affected by different water sources and different levels of compost application. It was noticed from the data obtained in Table (9) that the cultivation media had insignificant effect on vitamin $\mathrm{C}$. The cultivation of tomato in clay soil slightly increased vitamin $\mathrm{c}$ as compared to cultivation on rice straw bales.

Table (9): Vitamin C, total soluble solids and total acidity in tomato juice as affected by different treatments during growing season.

\begin{tabular}{|c|c|c|c|c|}
\hline Parameters & Treatments & $\begin{array}{c}\text { Vitamin C } \\
\mathrm{mg} / 100 \mathrm{~g}\end{array}$ & $\begin{array}{c}\text { TSS } \\
\%\end{array}$ & $\begin{array}{c}\text { Total } \\
\text { acidity } \\
\%\end{array}$ \\
\hline \multirow{6}{*}{ 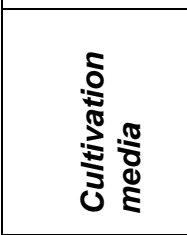 } & Rice straw bales & 3.90 & 1.76 & 13.69 \\
\hline & Clay soil & 3.91 & 1.88 & 13.58 \\
\hline & Average & 3.90 & 1.82 & 13.64 \\
\hline & F test & n.s & $* *$ & $* *$ \\
\hline & LSD at 0.05 level & --- & 0.08 & 0.09 \\
\hline & LSD at 0.01 level & --- & 0.14 & 0.12 \\
\hline \multirow{7}{*}{ 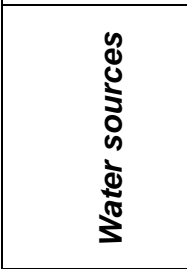 } & Fresh & 3.83 & 1.90 & 12.57 \\
\hline & Well & 3.83 & 1.98 & 15.30 \\
\hline & Blended & 4.05 & 1.58 & 13.05 \\
\hline & Average & 3.90 & 1.82 & 13.64 \\
\hline & F test & $\star *$ & $\star *$ & $\star \star$ \\
\hline & LSD at 0.05 level & 0.38 & 0.17 & 2.25 \\
\hline & LSD at 0.01 level & 0.52 & 0.23 & 3.48 \\
\hline \multirow{9}{*}{ 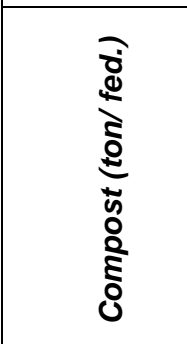 } & 0 & 2.44 & 1.16 & 11.93 \\
\hline & 5 & 3.13 & 1.54 & 12.93 \\
\hline & 10 & 4.02 & 1.79 & 13.50 \\
\hline & 15 & 4.59 & 2.13 & 14.46 \\
\hline & 20 & 5.35 & 2.48 & 15.37 \\
\hline & Average & 3.90 & 1.82 & 13.64 \\
\hline & F test & $\star * *$ & ** & ** \\
\hline & LSD at 0.05 level & 0.39 & 0.51 & 1.15 \\
\hline & LSD at 0.01 level & 0.52 & 0.65 & 1.37 \\
\hline \multirow{4}{*}{ 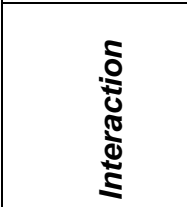 } & Cultivation $\times$ Water & $* *$ & $* *$ & $* *$ \\
\hline & Cultivation x Compost & n.s & * & ** \\
\hline & Water x Compost & n.s & ** & ** \\
\hline & Cultivation x Water x Compost & ** & ** & $\star \star *$ \\
\hline
\end{tabular}

Concerning the irrigation by different water quality, the data revealed that the blended fresh water with well water achieved the highest value of vitamin C (4.05 mg/100 mg). While the lowest value was obtained with irrigation by fresh water. With respect to the effect of compost on vitamin c, data indicate that the application of compost at 20 ton/fed. was superior to the other rates of compost . 
The interaction between cultivation media water sources and cultivation media $\mathrm{x}$ water sources $\mathrm{x}$ compost recorded highly significant effect on vitamin $\mathrm{C}$.

On the other hand, data of total soluble solids indicate that the cultivation media, different water sources and different rates of compost had highly significant effect on total soluble solids in juice of tomato. The data revealed that the cultivation in clay soil was superior to the rice straw bales. It is obvious from the data the irrigation by well water surpassed the irrigation by fresh water and blended fresh water with well water in increasing the total soluble solids.

Regarding the application of compost, the data indicated that the application of compost up to 20 ton/fed. achieved the highest value of total soluble solids as compared to other levels. The interaction between all the studied factors had significant effect on total soluble solids in juice of tomato.

Also, data in Table (9) illustrated that the cultivation of tomato in clay soil; irrigation by well water and application of 20 ton compost achieved the highest value of total acidity. While the lowest value of total acidity was obtained from combination between cultivation on rice straw bales, irrigation by fresh water and without application of compost.

\section{Effect of different treatments on $\mathrm{C} / \mathrm{N}$ ratio of rice straw bales after harvesting of tomato:}

Data in Table (10) indicated that $\mathrm{C} / \mathrm{N}$ ratio of rice straw bales is decreased after harvesting of tomato compared to those recorded before the experiment.

Table (10): $\mathrm{C} / \mathrm{N}$ ratio in rice straw bales as affected by different treatments after harvesting of tomato plants.

\begin{tabular}{|c|c|c|c|c|}
\hline $\begin{array}{l}\text { Irrigation } \\
\text { water }\end{array}$ & $\begin{array}{l}\text { Compost } \\
\text { Levels } \\
\text { (ton/fed.) }\end{array}$ & $\mathrm{C} \%$ & $\mathbf{N} \%$ & $\mathrm{C} / \mathrm{N}$ ration \\
\hline \multirow{6}{*}{ 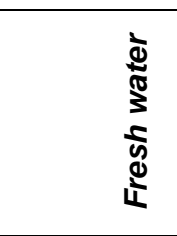 } & 0 & 25.30 & 0.38 & 66.58 \\
\hline & 5 & 17.91 & 1.18 & 15.18 \\
\hline & 10 & 20.90 & 1.52 & 13.75 \\
\hline & 15 & 19.88 & 1.74 & 11.43 \\
\hline & 20 & 21.10 & 1.88 & 11.22 \\
\hline & Average & 21.02 & 1.26 & 16.68 \\
\hline \multirow{6}{*}{ 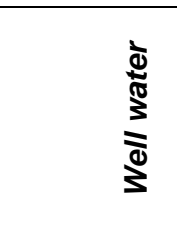 } & 0 & 25.30 & 0.38 & 66.58 \\
\hline & 5 & 23.17 & 0.99 & 23.40 \\
\hline & 10 & 20.63 & 0.90 & 22.92 \\
\hline & 15 & 19.63 & 0.87 & 22.56 \\
\hline & 20 & 19.22 & 0.88 & 21.84 \\
\hline & Average & 21.59 & 0.80 & 26.99 \\
\hline \multirow{6}{*}{ 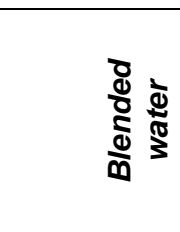 } & 0 & 25.30 & 0.38 & 66.58 \\
\hline & 5 & 23.13 & 1.10 & 21.02 \\
\hline & 10 & 20.02 & 0.96 & 20.85 \\
\hline & 15 & 21.16 & 1.10 & 19.24 \\
\hline & 20 & 19.86 & 0.89 & 22.31 \\
\hline & Average & 21.89 & 0.89 & 24.60 \\
\hline
\end{tabular}


The highest $\mathrm{C} / \mathrm{N}$ ratio values are obtained with control after harvesting of tomato (66.58). The obtained results show also that the use of fresh water leads to achieve the lowest values of $\mathrm{C} / \mathrm{N}$ ratio (16.68) comparing to well and blended water (26.99 and 24.60$)$ respectively. The increases of application rate of the compost leads to decrease $\mathrm{C} / \mathrm{N}$ ratio in rice straw bales, and thus indicates that the rice straw is completely decomposed and read to be safely used for soil improvement. The decreasing of $\mathrm{C} / \mathrm{N}$ ratios was happened at the highest rate of added compost due to increasing the rate of compost decomposition especially with fresh water or blended water. Whereas, well water tend to decrease the rate of decomposition. It is clear that $\mathrm{C} / \mathrm{N}$ ratio with different treatments is lower than the control. The lowest $\mathrm{C} / \mathrm{N}$ ratio is obtained from the interaction fresh water and 20 ton compost / fed. (11.22). This trend may be attributed to increase the biological activity with fresh water and high rate of compost, consequently increase the decomposition of rice straw and clearly decrease $\mathrm{C} / \mathrm{N}$ ratio. It is clear that $\mathrm{C} / \mathrm{N}$ ratio with different treatments is lower than the control.

\section{CONCLUSION}

On the bases of the obtained results, it could be concluded that using compacted rice straw bales as a growing media for replacing naturally infested soil can improve the production of tomato under greenhouse in Egypt.

Using rice straw bales as cultivation media resulted in decreasing tomato yield compared to clay soil. The fresh yield of tomato decreased with increasing irrigation water salinity, as well as, the rate of compost decomposition.

Generally, it could be concluded that compost application at the rate of 20 ton/fed. to rice straw bales as a growing media was the recommended treatment which produced the highest total tomato yield and quality fruits under greenhouse in Egypt. Thus, these treatments can replace completely or partially instead of mineral fertilizers, which protect the environment chemical pollution and its harmful effect on human and animal health besides reducing the production costs.

\section{Acknowledgments}

The authors wish to express their appreciations to the Director of "Soils, Water \& Environment Research Institute" as well as Chairman of "Soils Improvement \& Land Conservation Department" for providing facilities, supporting and valuable help in accomplishing this study. Also, our deepest thanks are offered to Prof. Dr. Anwar El-Abasery for his supporting of equipment and valuable advice concerning anhydrous this study. Thanks also extended to Prof. Dr. Mahmoud saied for his helpful guidance. 


\section{REFFRENCES}

A.O.A.C. (Association of Official Analytical Chemists) (1990). "Official Methods of Analysis," $15^{\text {th }}$ ed., Washington. D.C., USA.

Abo El-defan, T.R. (1990). Effect of organic manure on plant growth and nutrient uptake under saline condition. M.Sc. Thesis, Fac. Of Agric., Ain Shams Univ., Cairo Egypt.

Abo-soliman, M.S.M; M.M. saied; S. M. El-barbary and M.M. Ragab (2002). Saline water management for tomato production under greenhouses at North Nile Delta, Egypt. $2^{\text {nd }}$ inter. Conf. Hort. Sci. 10-12 sept. 2002. Kafr El-Sheikh. Tanta Univ. Egypt.

Anand, S. and N.P.S. Yaduranshi (2000). Effect of integrated nutrient management on soil properties and yield of rice in alkali soils. J. Endian Soc. Soil Sci., 48 (2):279-282.

Cheuke, W.; K.V. Lo, R.M.R. Branion and B. Fraser (2003). Benefits of sustainable waste management in the vegetable greenhouse industry. J. Environ. Sci. Heasth, 38: 855-863.

Cottenie, A.; Verso, M.; Kiekens, L.; Veighe, G. and R. Camerlynck (1982). Chemical Analysis of Plants and Soils. Lap. Anal. and Agrochem. State Univ., Gent. Belgium, Chapter 2, 3, PP.14-54.

El Aidy, F. (1986). Tomato production under simple protective tunnels in Egypt. Acta Hort. 190:511-514.

Gomez, K.A. and A.A. Gomez, (1984). "Statistical Procedures for Agricultural Research." $2^{\text {nd }}$ ed., p. 680, John Wiely and Sons New York.

Jackson,M.L(1967):Soil Chemical Analysis. Hall of Prentice India Ltd. New Delhi.

Janet F.M.Rippy, Mary M.Peet, Frank J. Louws, Paul V. Nelson, David B. Orr and Kenneth A. Sorensen (2004). Plant development and harvest yields of greenhouse tomatoes in six organic growing systems. HortScience, Vol. 39(2): 223-229.

Keener,H.M.; W.A. Dick and H. A. Hoitmk (2000). Composting and beneficial utilization of composted by products materials. In USA. Land application of agricultural, Industrial and municipal by products, SSS a book Series No.6: 315-341.

Klute, A. (1986). Methods of Soil Analysis. part $1.2^{\text {nd }}$ ed. ASA and SSSA. Madison.

Manishi, K.; Y. Funkumoto and T. Yoshido (1996). Effect of application of compost on growth and quality of tomatoes under stress due to rootzone restriction. Japan. J. of Soil and Plans Nutr., 67(3): 257-264 (C.F.CAB) abstract, $67: 2221$.

Mass,E.V.(1984): Salt tolerance of plants , In: Handbook of Plant Science in Agriculture,. B.R. Christie Ed, Florida, U.S.A.

Mizrahi, Y. and D.psternake (1985). Effect of salinity on quality of various agricultural crops. Plant and Soil 89:301-307.

Oslen, S.R., Colc and F.S. Watanabe (1954). Test of an ascorbic acid method for determining phosphorus in water and $\mathrm{NaHCO}_{3}$ extracts from soil. Soil Sci.Amr.Proc.29:677-678. 
Page, A. L., R.H.Miller and D.R.Keeny (1982). Methods of Soil Anaiysis. Part 2. Chemical and Microbiological Properties. Agron. 9, SSSA Madison, WI, USA.

Salem,N.(1988):Evaluation of some parameters influencing the use of conditioners in soils. Inter. Symp. On Soil Conditioners, Desert Researcher Center, Cairo,Egypt., PP. 81-91.

Selim, E.M., H.G.Abu El Fotoh and M.H.A.El-Mansy (2007).Productivity of tomato plants treated with some Biological, organic and inorganic fertilizers. Egypt. J. Soil. Sci. 47, No. 3 pp. 215-231.

تأثير بيئة النمو المعاملـة بنوعيـات مختلفة من ميـاه الرى و مستويات الكمبوست

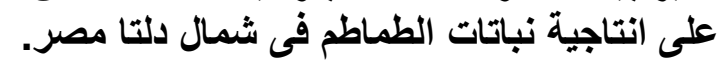

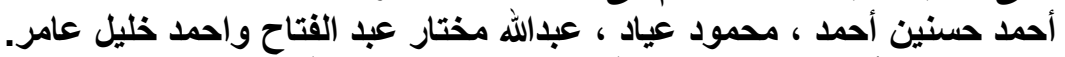
معهز بحوث الأراضى والمياه و البيئة. مركز البحوث الزئه الزراعية

أجريت تجربة فى صوب بلاستيكية بمحطة البحوث الزر اعية بسخا فى الموسم الثنتى الثي 2013

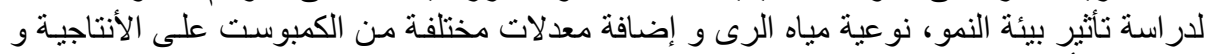

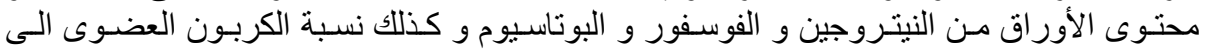

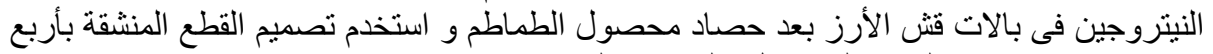

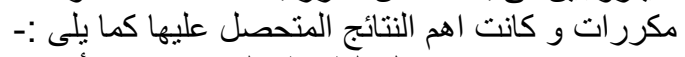

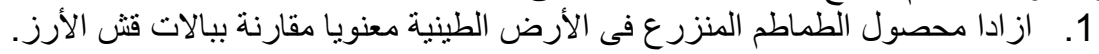

2.

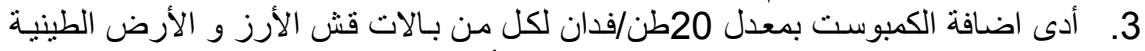

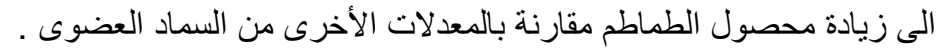

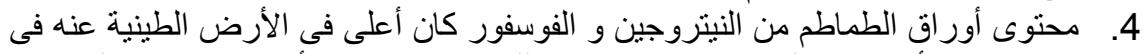

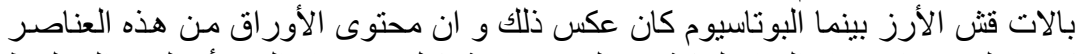

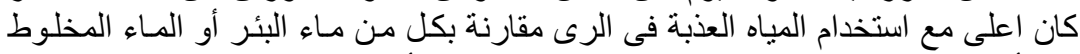

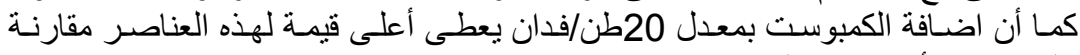

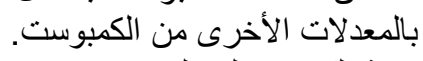

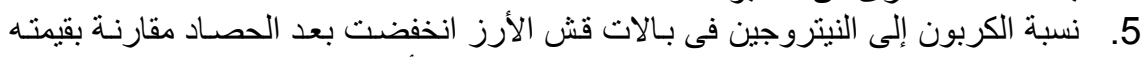

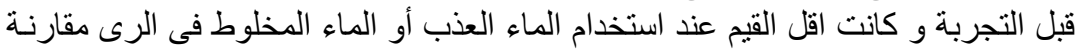

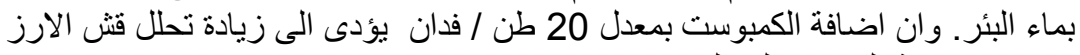
و وانخفاض نسبة الكربون الى النيتروجين.

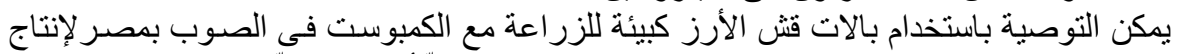

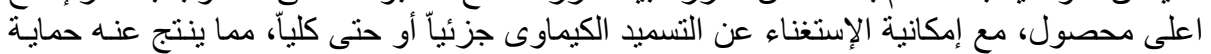

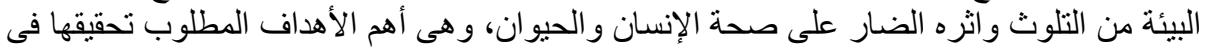
العالم،بالإضافة إلى خفض تكاليف الإنتاج . 